\title{
PENGARUH LATIHAN 40 YARDS SPRINT DAN 40 YARDS BACKPEDAL-FORWARD TERHADAP KECEPATAN DAN KELINCAHAN
}

\author{
Dendie Bagus Windiar ${ }^{1)}$, Karyna Alviyah Malinda ${ }^{2)}$ \\ Pascasarjana Pendidikan Olahraga \\ Universitas Negeri Surabaya \\ email : ${ }^{1}$ dendiewindiar@mhs.unesa.ac.id \\ karynadewolf@gmail.com
}

\begin{abstract}
ABSTRAK
Rancangan penelitian ini menggunakan matching only design, dan analisis data menggunakan Manova. Proses pengambilan data dilakukan dengan T-test untuk kelincahan dan 30 meter sprint test untuk kecepatan pada saat pretest dan posttest. Selanjutnya data hasil penelitian dianalisis dengan menggunakan bantuan SPSS seri 20. Hasil penelitian menunjukkan: (1) Nilai Sig. sebesar 0,000 lebih kecil dari 0,05 $(\mathrm{p}<0,05)$. Dengan kata lain terdapat pengaruh yang signifikan latihan 40 yards sprint terhadap peningkatan kecepatan (speed) dan nilai sig sebesar 0,007 lebih kecil dari 0,005 ( $\mathrm{p}<0,005$ ). Dengan kata lain terdapat pengaruh yang signifikan latihan 40 yards sprintterhadap kelincahan (agility); (2) Nilai Sig. sebesar 0,000 lebih kecil dari 0,05 $(\mathrm{p}<0,05)$. Dengan kata lain terdapat pengaruh yang signifikan latihan 40 yards backpedal-forward terhadap peningkatan kelincahan (agility) dan kecepatan (speed); (3) Nilai Sig. sebesar 0,000 lebih kecil dari 0,05 ( $<<0,05)$.
\end{abstract}

Kata Kunci : speed agility and quickness, 40 yards sprint, 40 yards backpedal-forward, kelincahan, kecepatan

\section{ABSTRACT}

Kind of this research is quantitative with quasi-experimental method. Design of the research uses matching only design, and analyzing data uses Manova. The process of obtaining the data is done by T-test for the agility and 30 meters sprint test for the speed on pretest and posttest. Afterwards the result of the research is analyzed by using SPSS 20. Result of the research shows: (1) Sig. Value of 0,000 is smaller than 0,05 ( $p<0,05)$. In other words, there is a significant effect of 40 yards sprint on the speed improvement and sig. Value of 0,000 is smaller than 0,05 $(p<0,05)$. In other words there is a significant effect of 40 yards sprint exercise on agility; (2) Sig. value of 0,000 is smaller than 0,05 ( $p<0,05)$. In other words there is a significant effect of 40 yards backpedal-forward on agility dan speed; (3) Sig. value of 0,000 is smaller than 0,05 $(p<0,05)$. In other words there is difference of the effect of 40 yards sprint and 40 yards backpedal-forward model exercise on agility and speed increase.

Keywords : speed agility and quickness, 40 yards sprint, 40 yards backpedal-forward, agility, speed

\footnotetext{
Alamat korespondensi:

E-mail: dendiewindiar@mhs.unesa.ac.id Info Artikel

Dikirim : 24 Mei 2019

Diterima : 25 Oktober 2019

DOI $\quad$ : https://doi.org/10.33503/jp.jok.v3i1.425
} 


\section{PENDAHULUAN}

Olahraga sangat berperan besar dalam menyehatkan tubuh. Peran olahraga sangat penting, karena dengan olahraga dapat menjamin kebugaran tubuh sehingga dapat melaksanakan aktivitas secara maksimal. Tujuan dari olahraga beragam sesuai dengan olahraga yang dilakukan, namun secara umum olahraga bertujuan memelihara kebugaran jasmani dan meningkatkan kualitas kesehatan tubuh. Olahraga dibagi menjadi tiga, yaitu olahraga pendidikan, olahraga prestasi, dan olahraga rekreasi.

Kecepatan adalah kemampuan otot untuk menjawab rangsangan dalam waktu sesingkat atau secepat mungkin (Sundari \& Sukadiyanto, 2019) Sedangkan kecepatan merupakan salah satu kemampuan dasar biomotorik yang diperlukan dalam setiap cabang olahraga. Tingkat kemampuan kecepatan seseorang sangat ditentukan oleh beberapa faktor, faktor-faktor yang ikut mempengaruhi kecepatan antara lain ditentukan oleh: keturunan, waktu reaksi, kekuatan, teknik, elastisitas otot, konsentrasi dan kemauan. Selain faktor tersebut jenis otot juga berpengaruh terhadap kecepatan yang dimiliki seseorang (T. O. Bompa \& Haff, 2009).

Menurut (Mutohir \& Maksum, 2007) kelincahan (agility) adalah kemampuan tubuh atau bagian tubuh untuk mengubah arah gerakan secara tibatiba dalam kecepatan yang tinggi. Pada saat mengubah arah gerakan tubuh secara berulang-ulang memerlukan kontraksi pada kelompok otot tertentu secara bergantian. Kemudian dengan cepat otot ini memacu tubuh ke arah posisi yang baru. Gerakan kelincahan menuntut terjadinya pengurangan kecepatan dan pemacuan momentum secara bergantian.

Terdapat salah satu bentuk latihan kecepatan dan kelincahan, yaitu $S A Q$ (Speed, Agility, and quickness). SAQ telah menjadi cara yang populer untuk melatih komponen fisik atlet khususnya kecepatan dan kelincahan. Dengan kebutuhan yang terus meningkat untuk mempromosikan kemampuan atletik, jenis pelatihan ini telah terbukti meningkatkan kemampuan seseorang dalam berbagai olahraga. Hal ini terjadikarena hampir setiap olahraga membutuhkan kecepatan dan kelincahan gerakan, baik lengan atau kaki (T. Bompa, 2012).

Kecepatan, kelincahan dan percepatan (reaksi waktu) adalah sistem pelatihan yang ditujukan untuk perkembangan kemampuan motorik dan kontrol 
gerakan tubuh melaluipengembangan sistem neuromuskuler. Hal ini bertujuan untuk meningkatkan kemampuan atlet untuk melakukan multi gerakan power dengan memprogram ulang sistem neuromuskuler, sehingga dapat bekerja lebih efisien (Vijayarani, Vallimurugan, \& Kumar, 2012). Menurut Jovanovic (Jovanovic, Sporis, Omrcen, \& Fiorentini, 2011) pelatihan $S A Q$ merupakan pelatihan yang akan memungkinkan atlet untuk mengerahkan kekuatan maksimal sehingga pola gerakannya terkontrol dan seimbang, khususnya dalam berolahraga. Dengan mempertimbangkan sistem energi yang terlibat dalam olahraga atlet, kekhususan pola gerakan, aksi otot, kecepatan dan jangkauan gerakan dilakukan dan kebutuhan khusus atlet, pelatihan $S A Q$ dapat memberikan pelatihan yang sangat spesifik dan rinci.

Dalam melakukan latihan kelincahan dan kecepatan reaksi variasi latihan sangat banyak dan beragam, akan tetapi dalam penelitian ini hanya digunakan dua bentuk latihan dari salah satu latihan $S A Q$ yaitu latihan 40-yard sprint dan 40-yard backpedal-forward.Ciri-ciri terjadinya proses adaptasi pada tubuh akibat dari latihan, antara lain pada: (1) kemampuan fisiologis ditandai dengan membaiknya sistem pernapasan, fungsi jantung, paru-paru, sirkulasi, dan volume darah, (2) meningkatnya kemampuan fisik, yaitu ketahanan otot, kekuatan dan power, (3) tulang, ligamen, tendo, dan hubungan jaringan otot menjadi lebih kuat (Sundari \& Sukadiyanto, 2019).

Berdasakan penjelasan dan beberapa uraian dari para ahli tentang pengaruh latihan yang menyebakan terjadinya proses adaptasi. Benar adanya bahwa latihan yang dilakukan secara kontinyu akan memberikan perkembangan dengan adanya proses adaptasi. Dengan demikian, maka latihan 40 yards backpedal-forward merupakan latihan yang utamanya melatih otot-otot kaki meliputi otot paha depan, paha belakang, betis, tungkai serta menguatkan ligamen dan tendon. Dengan demikian latihan 40 yards backpedal-forward dapat meningkatkan kecepatan dan kelincahan.

Meskipun memiliki jarak yang sama, pada 40 yards sprint harus merubah posisi tubuh untuk berlari ke depan sehingga waktu tempuhnya lebih cepat sedangkan pada 40 yards backpedal-forward tidak perlu merubah posisi tubuh sehingga ada gerakan berlari mundur. Sehingga latihan 40 yards sprint sangat 
berpengaruh terhadap kelincahan karena perlu merubah posisi dan arah tubuh dalam waktu sesingkat-singkatnya.

Beberapa penelitian yang relevan yaitu (Motimath, Kulkarni, \& Chivate, 2019) menyatakan dalam hasil penelitian menunjukkan bahwa pemain sepakbola menampilkan tingkat intensitas yang tinggi ketika diberikan latihan 40-yard dash. Menurut clark dkk (Clark, Rieger, Bruno, \& Stearne, 2017) bahwa latiha 40 yard dash dapat meningkatkan kecepatan maksimal seorang atlet NFL (National Football League). Dari uraian tersebut menunjukkan bahwa laihan 40 yard sprint dapat meningkatkan kelincahan secara signifikan. Menurut (Moore et al., 2007) latihan 40-yards dash dapat berpengaruh sangat signifikan terhadap laki-laki maupun perempuan pada usia remaja. (Prayuda \& Firmansyah, 2017) pengaruh latihan lari bolak-balik terhadap kecepatan, (Nuryadi \& Firmansyah, 2018) pengaruh latihan laddeer drill terhadap kecepatan lari 60 meter, pengaruh pelatihan ladder drill 90 degree rotation dan ladder drill ali shuffle terhadap peningkatan daya ledak otot tungkai dan kecepatan (Pelamonia \& Harmono, 2018).

Perbedaan pengaruh dari kedua latihan tersebut juga dapat dipengaruhi oleh beberapa faktor lain. Beberapa factor lain tersebut yaitu perbedaan kemampuan, dan motivasi diri dari setiap individu dalam mengikuti proses latihan. Perbedaan kemampuan sudah pasti disebabkan karena setiap individu memiliki kemampuan fisik yang berbeda, salah satunya dari segi fisiologis.. Faktor yang paling berpengaruh berdasarkan hasil pengamatan di lapangan yaitu faktor motivasi diri, minat atau kemauan. Sudah bukan rahasia lagi jika pada siswa sekolah ada yang bersungguh-sungguh ataupun malah sebaliknya. Hal ini terbawa dalam proses latihan yang diberikan, beberapa siswa melakukan latihan hanya karena tugas yang diberikan oleh guru ataupun peneliti. Sehingga beberapa siswa belum mengeluarkan seluruh kemampuan secara maksimal ketika latihan. Meskipun berhasil atau terdapat peningkatan, namun peningkatan yang terjadi tidak terlalu besar.

\section{METODE}


Jenis penelitian ini menggunakan pendekatan kuantitatif. Metode penelitian yang digunakan dalam penelitian ini yaitu metode penelitian eksperimen semu (quasi experiment). Penelitian eksperimen adalah penelitian yang dilakukan secara ketat untuk mengetahui hubungan sebab akibat di antara variable (Sugiyono, 2016). Eksperimen adalah jenis penelitian yang mana sampel atau objek penelitian diberikan suatu perlakuan (treatment) untuk mengetahui sebab-akibat antar variabel. Desain atau rancangan dalam penelitian menggunakan “Randomized Control Group Pretest-Posttest Design” (Arikunto, 2010). Dalam penelititian ini, peneliti membagi sampel menjadi tiga kelompok. Kelompok I adalah kelompok dengan latihan 40 yards sprint, kelompok II menggunakan latihan 40 yards backpedal-forward, sedangkan kelompok III adalah kelompok control.

Subjek dalam penelitian ini adalah siswa kelas X SMK Taruna Surabaya tahun pelajaran 2017/2018 yang berjumlah 115 siswa. Sampel yang diambil dalam penelitian ini adalah sejumlah 30 siswa yang dipilih secara random. Sebelum pelaksanaan dimulai peneliti memberikan tes awal (pretes) yaitu tes lari 30 meter dan T-tes terhadap sampel yang telah dipilih. Pada tahap pretes juga dilakukan penentuan jumlah reptisi maksimal yang digunakan untuk menentukan program latihan tiap siswa. Dari hasil pretes tersbut maka peneliti membagi 3 kelompok sampel. Alat yang digunakan sebagai pengumpulan data adalah meteran, stopwatch, dan bubuk kapur sebagai penanda garis.

Setelah dilakukan latihan selama 6 minggu maka sampel akan diberikan posttes. Dari hasil posttes tersebut dapat kita ketahui apakah terdapat pengaruh latihan 40 yards sprint dan 40 yards backpedal-forward terhadap kecepatan dan kelincahan.Data yang dikumpulkan pada setiap kelompok dianalisa secara deskriptif dan dilakukan uji persyaratan data. 1) uji normalitas data, menggunakan metode Kolmogorov-smirnov, 2) uji homogenitas, bertujuan untuk memastikan bahwa varian dari steiap kelompok adalah sama atau sejenis.

Selanjutnya dilakukan uji hipotesis untuk mengetahui sebrapa besar pengaruh yang ditimbulkan. 1) uji paired t-test, adalah untuk mengetahui seberapa besar perbedaan antara pretes dan postes. 2) uji analisis varian (one-way anova), untuk mengetahui perbedaan pengaruh perlakuan terhadap peningkatan kecepatan 
dan kelincahan sebelum dan setelah perlakuan antar kelompok. 3) analisis statistic $L S D$, untuk mengetahui perbedaan pengaruh antar kelompok.

\section{HASIL DAN PEMBAHASAN}

Berdasarkan penelitian yang telah dilakukan selama 6 minggu maka deskripsi data yang diperoleh adalah sebagai berikut:

Hasil Uji Hipotesis

a. Pengaruh Latihan 40 Yards Sprint terhadap kelincahan (agility) dan kecepatan (speed)

Untuk mengetahui pengaruh latihan 40 Yards Sprint maka langkah pengujiannya menggunakan uji-t yang dalam SPSS disebut sebagai paired t-test. Adapun hasil pengolahan datanya pada tabel di bawah ini.

Tabel 1. Hasil Uji Beda Variabel Dependent pada Kelompok 40 yards sprint

\begin{tabular}{l|l|l|l|l}
\hline Variable & Pair & $\mathrm{t}$-count & Sig. (2-tailed) & Status \\
\hline Agility & $\begin{array}{l}\text { Posttest }- \\
\text { Pretest }\end{array}$ & $-14,412$ & 0,000 & Different \\
\hline Speed & $\begin{array}{l}\text { Posttest }- \\
\text { Pretest }\end{array}$ & $-17,936$ & 0,000 & Different \\
\hline
\end{tabular}

Latihan 40 yards sprint memiliki pengaruh yang signifikan terhadap peningkatan kecepatan dan kelincahan dikarenakan dalam melakukan latihan ini, kaki senantiasa melakukan kontraksi secara terus menerus saat melakukan latihan tersebut. Otot- otot kaki senantiasa terlatih untuk terus melakukan kontraksi - kontraksi. Dalam latihan ini otot yang berpengaruh yaitu otot tungkai atas dan bawah. Otot - otot tungkai atas (otot paha) antara lain : Otot tensor fasialata, Otot abductor dari paha, Otot vastuslaterae, Otot rektus femoris, Otot satrorius, Otot vastus medialis, Otot abductor, Otot gluteus maxsimus, Otot paha leteral dan medial. Sedangkan otot tungkai bawah antara lain : Otot tibialis anterior, Otot ektensor digitorum longus, Otot gastroknemius, Otot tendon aciles, Otot soleus, Otot maleolus medialis, Otot retinakula bawah.

b. Pengaruh Latihan 40 Yards Backpedal-Forward terhadap kelincahan (agility) dan kecepatan (speed). 
Untuk mengetahui pengaruh latihan 40 Yards Backpedal-Forward, maka langkah pengujiannya menggunakan uji-t yang dalam SPSS disebut sebagai paired t-test. Adapun hasil pengolahan datanya pada tabel di bawah ini.

Tabel 2. Hasil Uji Beda Variabel Dependent pada Kelompok Eksperimen II

\begin{tabular}{l|l|l|l|l}
\hline Variable & Pair & $\mathrm{t}-$ count & Sig. (2-tailed) & Status \\
\hline Agility & $\begin{array}{l}\text { Posttest - } \\
\text { Pretest }\end{array}$ & $-3,514$ & 0,007 & Different \\
\hline Kecepatan & $\begin{array}{l}\text { Posttest - } \\
\text { Pretest }\end{array}$ & $-17,068$ & 0,000 & Different \\
\hline
\end{tabular}

Latihan 40 yards backpedal-forward memiliki pengaruh yang signifikan terhadap peningkatan kecepatan dan kelincahan dikarenakan kaki senantiasa melakukan kontraksi secara terus menerus saat melakukan latihan tersebut. Secara anatomi otot - otot yang berfungsi saat melakukan gerakan latihan 40 yards backpedal-forward untuk meningkatkan kecepatan dan kelincahan adalah otot tungkai atas dan bawah. Pada dasarnya terdiri dari dua kelompok otot yang bekerja secara berlawanan atau antagonis, yaitu fleksi dan ekstensi. Pada saat melakukan gerakan menekuk atau fleksi maka kelompok otot yang bekerja adalah otot fleksio, sedangkan otot-otot ekstensi hanya bekerja meluruskan. Demikian sebaliknya kelompok otot ektensi memanjang dan fleksi memendek.

Berdasarkan pada kedua tabel di atas terdapat perbedaan sebelum dan setelah perlakuan dari masing-masing variabel dependent (kelincahan dan kecepatan) baik pada kelompok eksperimen I maupun kelompok eksperimen II. Hal ini menunjukkan bahwa tingkat signifikansi dari masing-masing variabel sebesar 0,000 atau dengan kata lain $P<0,05$. Sehingga dapat disimpulkan bahwa ada perbedaan setelah diberi latihan 40 yards backpedal-forward dan 40 yards sprint.

c. Hasil Uji Beda Variabel Dependent Antar Kelompok

Untuk mengetahui perbedaan variabel dependent antar kelompok digunakan analisis varians. Sebagaimana yang telah dijelaskan sebelumnya bahwa untuk menguji hipotesis dapat dilakukan setelah data berdistribusi normal dan homogen. Oleh karena kriteria tersebut telah terpenuhi maka langkah selanjutnya dapat dipergunakan multivariate analysis of variance. Untuk keperluan multivariate 
analysis of variance, maka data kelompok kontrol diuji secara bersama-sama dengan data kedua kelompok eksperimen. Adapun hasil dari uji Manova adalah menguji perbedaan perbedaan hasil selisih dari variabel terikat yaitu kecepatan dan kelincahan dalam kelompok didasarkan pada variabel bebas dapat dilakukan dengan uji multivariate test.

Apabila terdapat perbedaan pengaruh antar kelompok maka analisis dilanjutkan menggunakan uji post hoc multiple comparations dengan menggunakan analisis least significant diffrence (LSD) dalam program SPSS seri 20 sebagai upaya untuk melihat variabel independent mana yang memberikan pengaruh secara signifikan terhadap peningkatan variabel dependent.

Hasil dari uji post hoc dengan LSD untuk variabel kelincahan (Kelincahan) dapat dilihat pada tabel 3. sebagai berikut:

Tabel 3. Hasil dari uji post hoc dengan LSD untuk variabel kelincahan

\begin{tabular}{l|l|l|l}
\hline \multirow{2}{*}{ Groups } & $\begin{array}{l}\text { Mean } \\
\text { difference }\end{array}$ & Significance (p) \\
\hline \multirow{2}{*}{ Group I } & Kelompok II & $-1,4510^{\prime}$ & 0,000 \\
\cline { 2 - 4 } & Control & $-1,8610$ & 0,000 \\
\hline \multirow{2}{*}{ Kelompok II } & Kelompok I & $1,4510^{\prime}$ & 0,000 \\
\cline { 2 - 4 } & Control & $-0,4100^{\prime}$ & 0,223 \\
\hline \multirow{2}{*}{ Kontrol } & Kelompok I & 1,8610 & 0,000 \\
\cline { 2 - 4 } & Kelompok II & 0,4100 & 0,223 \\
\hline
\end{tabular}

Dari tabel 3 menunjukan bahwa adanya perbedaan yang signifikan diantara ketiga kelompok. Perbedaan tersebut dapat dilihat dari mean difference. Sehingga dari mean difference tersebut memberikan sebuah makna perbedaan pengaruh terhadap peningkatan kelincahan antar kelompok penelitian. Hal ini dapat diketahui dari nilai mean difference, bahwa kelompok eksperimen I lebih optimal peningkatan kelincahan dibandingkan dengan kelompok eksperimen II maupun kelompok kontrol.

Demikian pula pada kecepatan menunjukkan bahwa kelompok eksperimen II lebih optimal dibanding kelompok yang lain, sebagaimana terlihat pada tabel 4 di bawah ini. 
Tabel 4. Hasil uji beda

\begin{tabular}{l|l|l|l}
\hline \multirow{2}{*}{ Kelompoks } & $\begin{array}{l}\text { Mean } \\
\text { difference }\end{array}$ & Significance (p) \\
\hline \multirow{2}{*}{ Kelompok I } & Kelompok II & $-0,3950{ }^{\prime}$ & 0,021 \\
\cline { 2 - 4 } & Kontrol & $-1,1690^{\prime}$ & 0,000 \\
\hline \multirow{2}{*}{ Kelompok II } & Kelompok I & 0,3950 & 0,021 \\
\cline { 2 - 4 } & Kontrol & $-0,7740$ & 0,000 \\
\hline \multirow{2}{*}{ Kontrol } & Kelompok I & $1,1690^{\prime}$ & 0,000 \\
\cline { 2 - 4 } & Kelompok II & 0,7740 & 0,000 \\
\hline
\end{tabular}

Dari tabel 4 menunjukkan bahwa ada perbedaan signifikan diantara ketiga kelompok. Perbedaan tersebut dapat dilihat pada mean difference, sehingga dari perbedaan tersebut memberikan sebuah makna perbedaan pengaruh terhadap peningkatan kecepatan antar kelompok penelitian. Dengan demikian dari hasil uji beda dependent antar kelompok dari variabel dependent (kelincahan dan kecepatan) dapat disimpulkan bahwa latihan 40 yards sprint memberikan peningkatan yang lebih besar dari latihan 40 yards backpedal-forward maupun pelatihan pada kelompok kontrol.

\section{SIMPULAN}

Berdasarkan hasil penelitian dan pembahasan tentang pengaruh latihan Speed Agility and Quickness (SAQ) model 40 yards backpedal-forward dan 40 yards sprint terhadap kelincahan (agility) dan kecepatan (speed), yang telah diuraikan pada bab sebelumnya maka dapat dikemukanan simpulan penelitian sebagai berikut: Terdapat pengaruh yang signifikan program latihan 40 yards sprint terhadap peningkatan kecepatan (speed). Terdapat pengaruh yang signifikan program latihan 40 yards sprint terhadap peningkatan kelincahan (agility). Terdapat pengaruh yang signifikan program latihan 40 yards backpedal-forward terhadap peningkatan kecepatan (speed). Terdapat pengaruh yang signifikan program latihan 40 yards backpedal-forward terhadap peningkatan kelincahan (agility). Terdapat pengaruh yang signifikan program latihan 40 yards sprint dan 40 yards backpedal-forward terhadap peningkatan kecepatan (speed). Terdapat pengaruh yang signifikan program latihan 40 yards sprint dan 40 yards backpedal-forward terhadap peningkatan kelincahan (agility).

Meskipun memiliki jarak yang sama, pada 40 yards sprint harus merubah posisi tubuh untuk berlari ke depan sehingga waktu tempuhnya lebih cepat 
sedangkan pada 40 yards backpedal-forward tidak perlu merubah posisi tubuh sehingga ada gerakan berlari mundur. Sehingga latihan 40 yards sprint sangat berpengaruh terhadap kelincahan dan kecepatan karena perlu merubah posisi dan arah tubuh dalam waktu sesingkat-singkatnya untuk berlari ke depan.

Hasil penelitian ini sejalan dengan hasil penelitian yang dilakukan (Clark et al., 2017) bahwa latihan 40 yard dash dapat meningkatkan kecepatan maksimal seorang atlet NFL (National Football League). Sehingga hasil penelitian bisa menjadi penguat teori tentang latihan yang fokus dengan latihan 40 Yards Sprint dan 40 Yards Backpedal-Forward.

\section{DAFTAR RUJUKAN}

Arikunto, S. (2010). Prosedur Penelitian Pendekatan Praktik Edisi Revisi VI. Rineka Cipta.

Bompa, T. (2012). Annual Planning, Periodisation and Its Variations. FISA Coaching Development Programme.

Bompa, T. O., \& Haff, G. G. (2009). Periodization: Theory and Methodology of Training. 5th ed. Champaign, Ill. : Human Kinetics;

Clark, K. P., Rieger, R. H., Bruno, R. F., \& Stearne, D. J. (2017). The NFL Combine 40-Yard Dash. Journal of Strength and Conditioning Research. https://doi.org/10.1519/JSC.0000000000002081

Jovanovic, M., Sporis, G., Omrcen, D., \& Fiorentini, F. (2011). Effects of speed, agility, quickness training method on power performance in elite soccer players. Journal of Strength and Conditioning Research. https://doi.org/10.1519/JSC.0b013e3181d67c65

Moore, A. N., Decker, A. J., Baarts, J. N., DuPont, A. M., Epema, J. S., Reuther, M. C., ... Mayhew, J. L. (2007). Effect of competitiveness on forty-yard dash performance in college men and women. Journal of Strength and Conditioning Research. https://doi.org/10.1519/R-19495.1

Motimath, B., Kulkarni, A. A., \& Chivate, D. (2019). 40 Yard dash test in young athletes of belagavi city-An exploratory study. Indian Journal of Physiotherapy and Occupational Therapy - An International Journal. https://doi.org/10.5958/0973-5674.2019.00003.0 
Mutohir, T. C., \& Maksum, A. (2007). Sport Development Index. Jakarta: Kemenpora.

Nuryadi, A., \& Firmansyah, G. (2018). Pengaruh Latihan Ladder Drill Terhadap Kecepatan Lari 60 Meter Di Sekolah Basket. Jp.jok (Jurnal Pendidikan. Jasmani , Olahraga Dan Kesehatan), 2(1), 63-69.

Pelamonia, S. P., \& Harmono, B. A. (2018). Pengaruh Pelatihan Ladder Drill 90 Degree Rotation Dan Ladder Drill Ali Shuffle Terhadap Peningkatan Daya Ledak Otot Tungkai Dan Kecepatan. Jp.jok (Jurnal Pendidikan. Jasmani, Olahraga Dan Kesehatan), 2(1), 20-29.

Prayuda, A. Y., \& Firmansyah, G. (2017). Pengaruh Latihan Lari 12 Menit Dan Lari Bolak Balik Terhadap Peningkatan Daya Tahan Vo2 max. Jp.jok 1(1), $13-22$.

Sugiyono, P. D. metode penelitian kuantitatif, kualitatif,dan R\&D, Alfabeta, cv. (2016).

Sundari, A., \& Sukadiyanto, S. (2019). Perbandingan metode latihan dan power otot lengan terhadap hasil tolak peluru. Jorpres (Jurnal Olahraga Prestasi). https://doi.org/10.21831/jorpres.v15i1.26022

Vijayarani, C. A., Vallimurugan, V., \& Kumar, M. S. (2012). Influence of yogic practices on selected physiological and psychological variables of adolescents boys. Recent Research in Science \& Technology. 